\title{
Validation of Expanded Scale of Impulse Buying in Sports
}

\author{
${ }^{1}$ Hosein Hasanpoor, ${ }^{1}$ Farshad Tojari ${ }^{*},{ }^{1}$ Zinat Nikaeen \\ ${ }^{1}$ Department of Sport Management, Faculty of Physical Education and Sport Sciences, Central Tehran \\ Branch, Islamic Azad University, Tehran, Iran.
}

Submitted 23 May 2018; Accepted in final form 07 July 2018.

\begin{abstract}
Background. Impulse buying is a complicated human buying behavior. It is influenced by factors such as income level, consumption pattern, lifestyle changes, sociocultural variables, and increased buying power. Under its influence, consumers buy unreasonably and in an unplanned fashion. Objectives. The objective of this study is to develop and validate the impulse buying evaluation scale proposed by Nazari \& Ghaderi (2011). Methods. The statistical population consisted of 598 customers of sports stores who were selected by convenience sampling. In this study, Kolmogorov-Smirnov (K-S) test was used to verify the natural distribution of data, Cronbach's alpha was used to determine internal consistency, KMO test was used to determine sampling adequacy, exploratory factor analysis was used to initially identify items, and confirmatory factor analysis was used to examine the construct's validity and to confirm the factor structure of the scale. Results. The findings show that all the subscales examined-including factors related to product, situational, psychological-behavioral, and impulse buying - have good reliability and validity. Conclusion. Therefore, this scale could be used to measure impulse buying behavior of customers of sports stores, based on which more efficient sports marketing plans can be developed.
\end{abstract}

KEY WORDS: Validation, Impulse Buying, Sports Customer, Situational Factors, Psychological Factors, Product Related Factors.

\section{INTRODUCTION}

Impulse buying is an unplanned, convincing, complicated, and enjoyable buying behavior that has recently been widely studied in universities and business centers (business enterprises). The results of some studies show that about $40 \%$ buys occur impulsively; so, over the last two decades, a significant effort has been made to identify factors affecting impulse buying, such as productrelated factors, consumer characteristics, store conditions, and situational stimuli $(1,2)$. This behavior was considered for the first time by Vernon-Kellor and has since then been addressed as an important topic in marketing activities (3).
Impulse buying is always a major concern for marketers and analysts. So, many of them use incentive advertising in business plans to increase their rate of impulse buying (4).

Although there has been a lot of research on the behavior of impulse buying during the last two decades, there is little such research in the field of sports. Nonetheless, even from this small body of work it is apparent that a high percentage of trade is done impulsively in sports markets as well: nearly $36 \%$ of men's sports buys and $54 \%$ of women's sports buys are impulsive (5). In sports markets, impulse buying is an immediate trend

*. Corresponding Author:

Farshad Tojari, Professor

Department of Sport Management, Faculty of Physical Education and Sport Sciences, Central Tehran Branch, Islamic Azad University, Po.Box: 1955847781, Velayat University Complex, Salman St., Khandan St., Ghaem Sq., Artesh Blvd., Sohanak, Tehran, Iran.

E-mail: farshad.tojari@gmail.com 
towards buying which gets formed in the sports consumer. For example, the desire of sports lovers towards impulse buying of sports products increases when sports consumers are going to buy products related to their favorite sports teams (6). Customers' willingness to undertake impulse buying is associated with customers' impulsivity: sports customers often prefer the interests of their favorite sports team's symbols than thinking about the products they buy. Therefore, the symbolic nature of products attributed to sports teams affects the perceived value of the product by sports consumers (7). On the other hand, psychological and social structures can affect the occurrence of impulse buying behavior in sport consumers beyond brands and the assignment of a product to popular sports teams. Impulsivity and impulse behavior as an individual attribute leads to the desire of sports consumers to commit impulse buying of sports products. Results show that impulsivity and impulsive behavior of sports consumers have a positive effect on their incidence of impulse buying behavior: the personal attributes of many sports consumers act as psychological motivations for consumption (710).

Research results show that situational factors (such as environmental enticements, ease of access and search, individual buys, available money, vendor tips) and factors related to product features (such as product promotions, advertising effects, and product brand) are effect the occurrence of impulse buying behavior (9-17). Also, the effects of individual characteristics (such as gender, social class, education, age, and income) and psychological and behavioral characteristics (tendency to impulse buying, selfesteem, individualism, autonomy of action, extraversion, self-confidence, emotional stability, socialization, order, change, dependence, flexibility, and pragmatism) on the tendency of customers towards impulse buying has been confirmed (17-19). However, these factors are usually presented in a non-categorized form, or individually, or in different categories that are appropriate to the nature of the research, such as factors related to the individual, factors related to the products, and factors associated with the store $(9,10)$.

Therefore, considering that there is no proper framework for categorizing the factors affecting impulse buying behavior, especially in the field of sports, that the identified factors are scattered in different researches, and that many factors have not even been investigated yet, this research tries to develop an interested scale in terms of the number of factors studied in the field of sports. It also aims to achieve a valid framework for categorizing the factors affecting the behavior of impulse buying in sports.

Considering that psychological-behavioral factors, product-related factors, situational factors, and demographic factors have had the greatest attractiveness for researchers, the current scale is designed to match these factors. Given the theoretical infrastructure and researches conducted, the present study seeks to test and validate the developed scale of impulse buying in sports in order to develop previous findings and discover new subjects. In general, the main hypothesis of the research is expressed in such a way that the scale developed to determine the factors affecting impulse buying behavior of sports consumers has reliability and validity.

\section{MATERIALS AND METHODS}

Participants. The statistical population included 598 customers of Tehran's sports product stores. It included 311 men and 287 women, who were selected by convenience sampling and voluntarily took part in completing the questionnaire.

Measurement Tools. The initial scale of the research (Ghader \& Nazari, 2011) included personal information and impulse buying related questions that were expressed in 37 items and included the following five subscales: demographic, situational, psychological, mixed marketing, and impulse buying. All the components of this scale were reported to have a favorable coefficient for Cronbach's alphaabove 75 , i.e. the attitude toward these items was arranged with the use of the 5-point Likert scale from fully agree to fully disagree. In this scale, the demographic subscale of the dimensions of age and gender were determined in 2 items; situational subscale of buying environment, seller's guidance, and individual buying in 8 items; psychological-behavioral subscale of individualism, excitement, and self-esteem in 12 items; the mixed marketing of promotions, price, and product type in 8 items; and subscale of impulse buying in 7 items.

In the present study, based on studied theoretical foundations and summing up the studies conducted, about 50 of the most frequent 
items were identified and categorized in four general categories. After a survey of sports management professors and a study between limited examples, the final scale was provided in 35 items and 5 subscales, including demographic factors, situational factors, psychologicalbehavioral factors, product-related factors, and impulse buying. The attitude to the items was also provided with a 5-point Likert scale from fully agree to fully disagree. In the demographic subscale, the following 10 items were explained: age, gender, marital status, income level, level of education, athletic skill level, social class, type of sport, interest in the sports team, and interest in the brand. In the situational subscale, the following 7 items were explained: showcase view, seller's guidance, shopping environment, store search, enough money, enough time, and attractive store environment. In the psychological-behavioral subscale, 6 items were explained: self-esteem, self-confidence, excitement, excitability, extraversion, and buying pleasure. In the subscale related to productrelated factors, 5 items were explained: product life, promotion and sales strategies, promotions, price, and brand. Finally, the subscale of impulse buying was explained through 7 items.

Statistical Analysis. The statistical methods used in this research were descriptive statistics, such as mean, standard deviation, minimum, maximum, frequency, frequency percentage, and chart and tables for summarization, classification, and characterization of individual characteristics and variables of the research. To verify the normal distribution of the data (regarding more than 50 observations), the Kolmogorov-Smirnov test (K-S) was used; Cronbach's alpha was used to determine the internal consistency; the KMO test was used to determine the sampling adequacy; the exploratory factor analysis method was used for the initial identification of items and validity of components of each subscale; confirmatory factor analysis was used to examine the construct's validity and confirm the factor structure of the scale. In other words, through exploratory factor analysis, the validity of the components of the variables was determined first, and then the results of the exploratory factor analysis were verified using the confirmatory factor analysis. All analyses were performed at 95\% confidence level using SPSS-pc ++ and LISREL software.

\section{RESULTS}

Demographic findings showed that participants were male (70\%), married $(71 \%)$, and employees $(60 \%)$. Most of them were 31 to 40 (43.1) year old. The education level of most of the participants (42\%) was undergraduate and graduate, and most of them had an income level $(60 \%)$ between one to three millions.

The results of the exploratory factor analysis in Table 1 show that the following factors had an acceptable value and, consequently, an appropriate internal correlation: 6 items related to situational factors (beautiful showcase of the store, attractive store environment, guidance and conversation skills of sellers, shop search, individual buying, and enough money) with a mean Cronbach's alpha of 0.7092, 7 items related to psychological-behavioral factors (self-esteem, self-confidence, excitability, extraversion, buying pleasure, and rapid decision making) with a mean Cronbach's alpha of $0.7039,5$ items of productrelated factors (product type, strategy sale, discount, price, and brand) with a mean Cronbach's alpha of 0.7039 , and 7 buying items related to impulse buying with a mean Cronbach's alpha of 0.7039 .

Figure 1 shows that the factor loads derived from the confirmatory factor analysis of items of situational factor subscales in each case are greater than 0.3 (the least acceptable value): 6 items related to this variable can be categorized in a separate factor.

Figure 2 shows that the factor loads derived from the confirmatory factor analysis of items of psychological-behavioral factors in each case were greater than 0.3 (minimum acceptable value) and, therefore, the 7 items related to this variable can be categorized in a separate factor.

Figure 3 shows that the factor loads derived from the confirmatory factor analysis of items of product-related factors in each case were greater than 0.3 (minimum acceptable value) and, therefore, the 5 items related to this variable can be categorized in a separate factor.

Figure 4 shows that shows that the factor loads derived from the confirmatory factor analysis of items of psychological-behavioral in each case were greater than 0.3 (minimum acceptable value): therefore, the 7 items related to this variable can be categorized in a separate factor. 
Table 1. Results of the exploratory factor analysis of the items of the scale of factors affecting impulse buying in sports customers

\begin{tabular}{|c|c|c|c|c|}
\hline Factors & Items & $\begin{array}{l}\text { Load } \\
\text { factor }\end{array}$ & $\begin{array}{l}\text { Variance } \\
\text { factor }\end{array}$ & $\begin{array}{l}\text { Cronbach's } \\
\text { alpha }\end{array}$ \\
\hline \multirow{6}{*}{ Situational factors } & $\begin{array}{l}\text { When I come to a beautiful showcase, I'd like to go } \\
\text { to the store. }\end{array}$ & 0.43 & \multirow{6}{*}{18.47} & \multirow{6}{*}{0.7092} \\
\hline & $\begin{array}{l}\text { Attraction of the store environment increases my } \\
\text { tendency to buy more. }\end{array}$ & 0.42 & & \\
\hline & $\begin{array}{l}\text { A skilled seller makes me buy a product that I did } \\
\text { not intend to buy. }\end{array}$ & 0.77 & & \\
\hline & $\begin{array}{l}\text { I'll search carefully everywhere in the store before } \\
\text { buying. }\end{array}$ & 0.89 & & \\
\hline & $\begin{array}{l}\text { When I go shopping alone, I am more comfortable } \\
\text { to buy and test brands or new products. }\end{array}$ & 0.89 & & \\
\hline & $\begin{array}{l}\text { When I have enough money, I might buy something } \\
\text { which was not in my list and I did not plan to buy it. }\end{array}$ & 0.83 & & \\
\hline \multirow{7}{*}{$\begin{array}{l}\text { Psychological- } \\
\text { behavioral factors }\end{array}$} & $\begin{array}{l}\text { I am able to do my work better than the rest of the } \\
\text { people. }\end{array}$ & 0.83 & \multirow{7}{*}{18.53} & \multirow{7}{*}{0.7039} \\
\hline & I value and respect myself in my life. & 0.74 & & \\
\hline & When I'm going to buy something, I'm excited. & 0.81 & & \\
\hline & $\begin{array}{l}\text { When I'm going to buy a new product, I'll get advice } \\
\text { from others. }\end{array}$ & 0.5 & & \\
\hline & $\begin{array}{l}\text { Buying items for my favorite sports and team makes } \\
\text { me happy and enjoyed. }\end{array}$ & 0.71 & & \\
\hline & I always buy whatever I like something. & 0.80 & & \\
\hline & Mostly I quickly make a decision to buy. & 0.56 & & \\
\hline \multirow{5}{*}{$\begin{array}{l}\text { Product -related } \\
\text { factors }\end{array}$} & $\begin{array}{l}\text { I think thoroughly before buying products that I buy } \\
\text { less often, like sports shoes or coat. }\end{array}$ & 0.94 & \multirow{5}{*}{17.98} & \multirow{5}{*}{0.7239} \\
\hline & Auctions and discounts encourage me to buy. & 0.31 & & \\
\hline & $\begin{array}{l}\text { An interesting offers, such as echantillon or buy, } \\
\text { take two, encourages me to buy. }\end{array}$ & 0.42 & & \\
\hline & $\begin{array}{l}\text { I think the price of a product is an important reason } \\
\text { for choosing it. }\end{array}$ & 0.87 & & \\
\hline & $\begin{array}{l}\text { In my opinion, the brand of a product is an } \\
\text { important reason for choosing it. }\end{array}$ & 0.94 & & \\
\hline \multirow{6}{*}{$\begin{array}{l}\text { Impulse buying } \\
\text { factors }\end{array}$} & I always plan or prepare a list for my buying. & 0.83 & \multirow{6}{*}{19.02} & \multirow{6}{*}{0.7052} \\
\hline & $\begin{array}{l}\text { When I get a product related to my favorite sports } \\
\text { or team, I buy it, even if I'd not planned to buy it. }\end{array}$ & 0.93 & & \\
\hline & I feel uncomfortable after I buy unplanned. & 0.62 & & \\
\hline & I often buy spontaneously. & 0.93 & & \\
\hline & $\begin{array}{l}\text { Before buying anything, I compare it with a similar } \\
\text { product or brand. }\end{array}$ & 0.58 & & \\
\hline & $\begin{array}{l}\text { When something attracts me, I buy it without } \\
\text { thinking about other options. }\end{array}$ & 0.94 & & \\
\hline
\end{tabular}




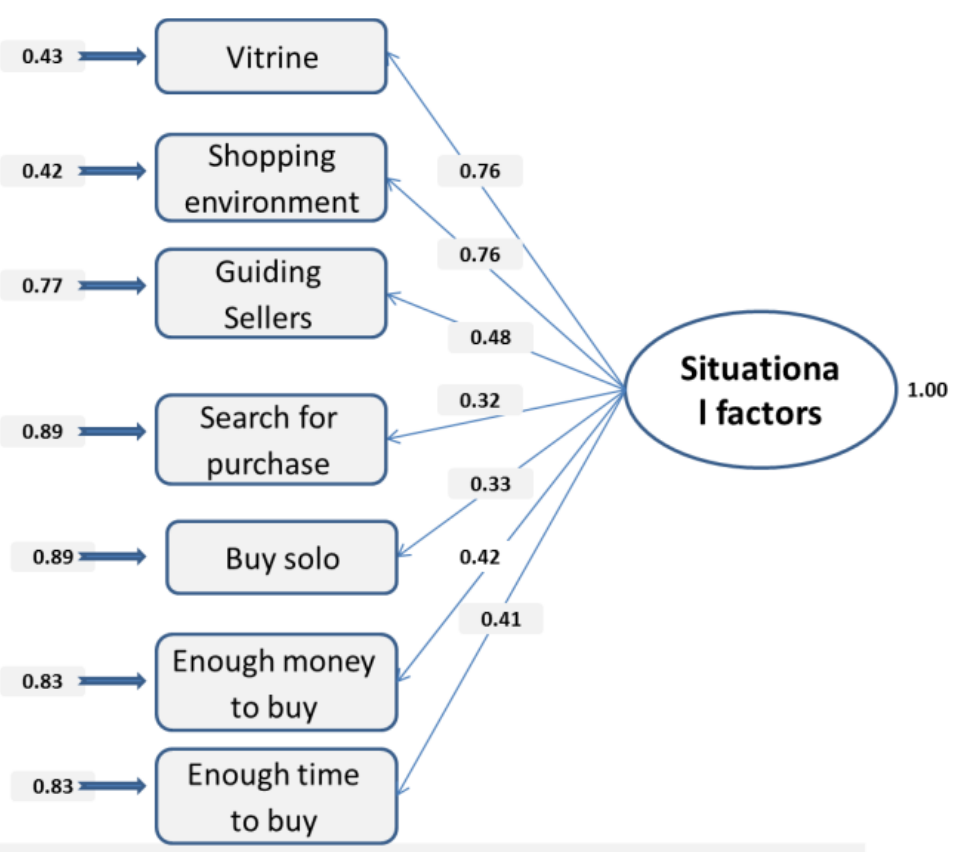

Chi-squared: 40.65

Df: 14

$p$ value :0.00

RMSEA: 0.041

Figure 1. Confirmatory factor analysis chart of situational factor subscales affecting impulse buying in sports customers

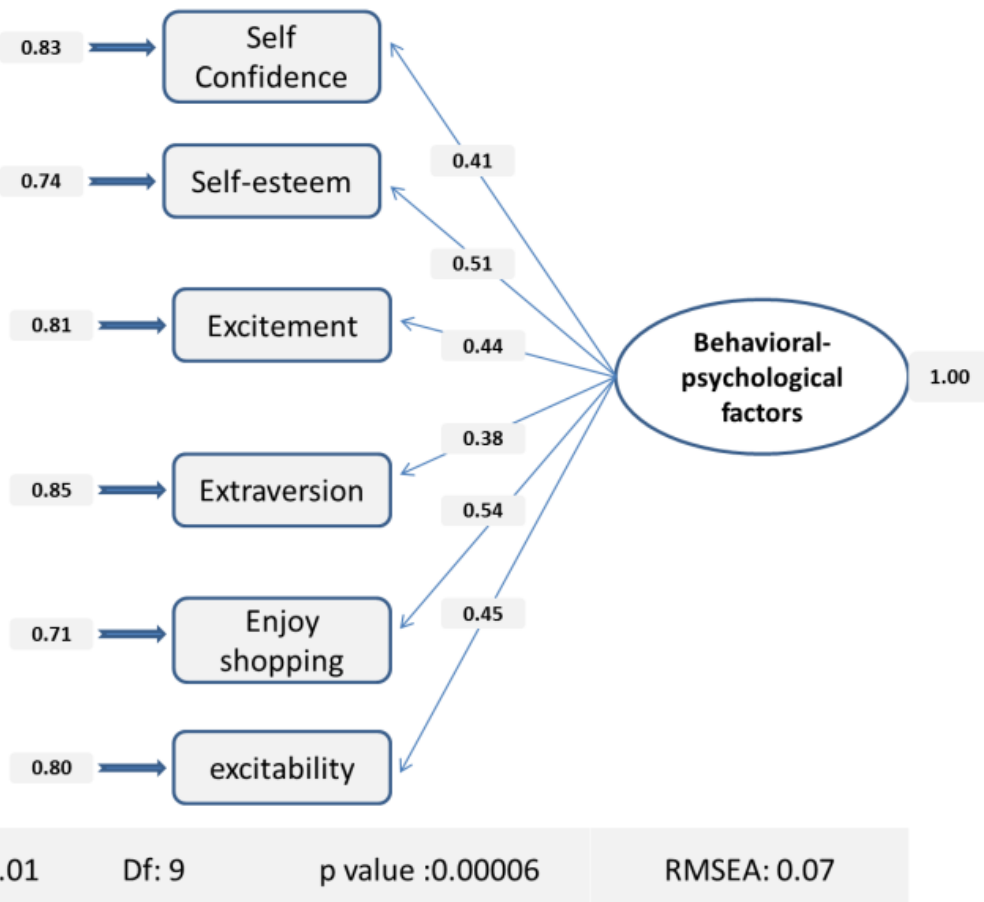

Figure 2. Confirmatory factor analysis chart of psychological-behavioral subscales affecting impulse buying in sports customers 


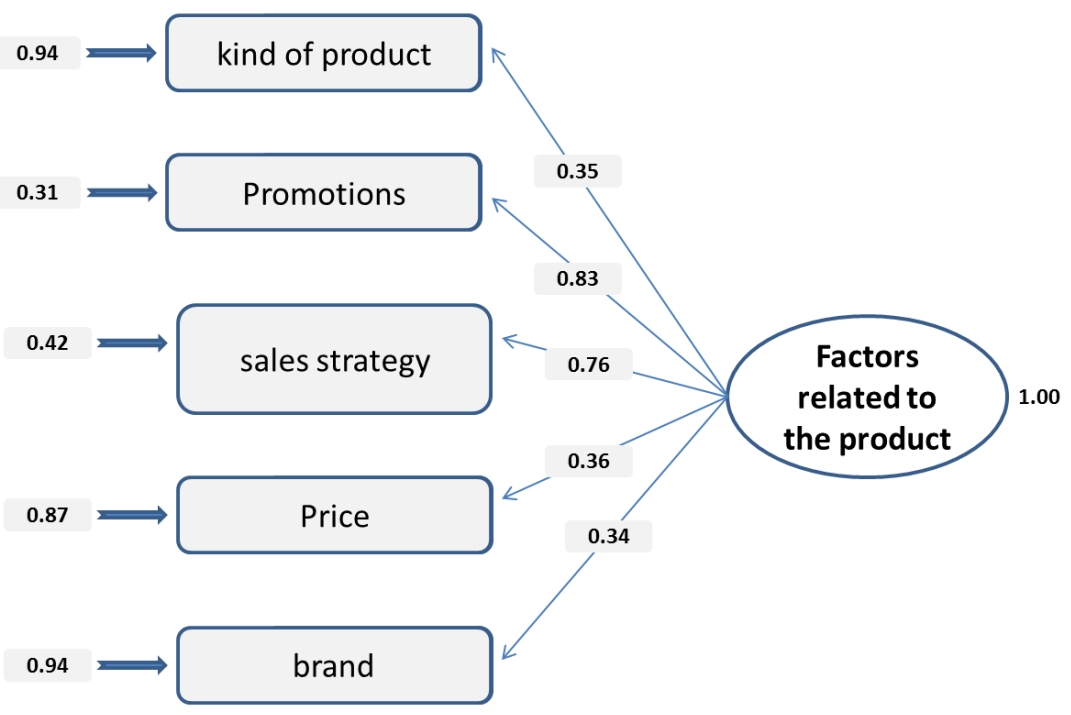

Chi-squared: 11.87

Df: 5

$p$ value $: 0.00$

RMSEA: 0.052

Figure 3. Confirmatory factor analysis chart of subscale of factors related to product affecting impulse buying in sports customers

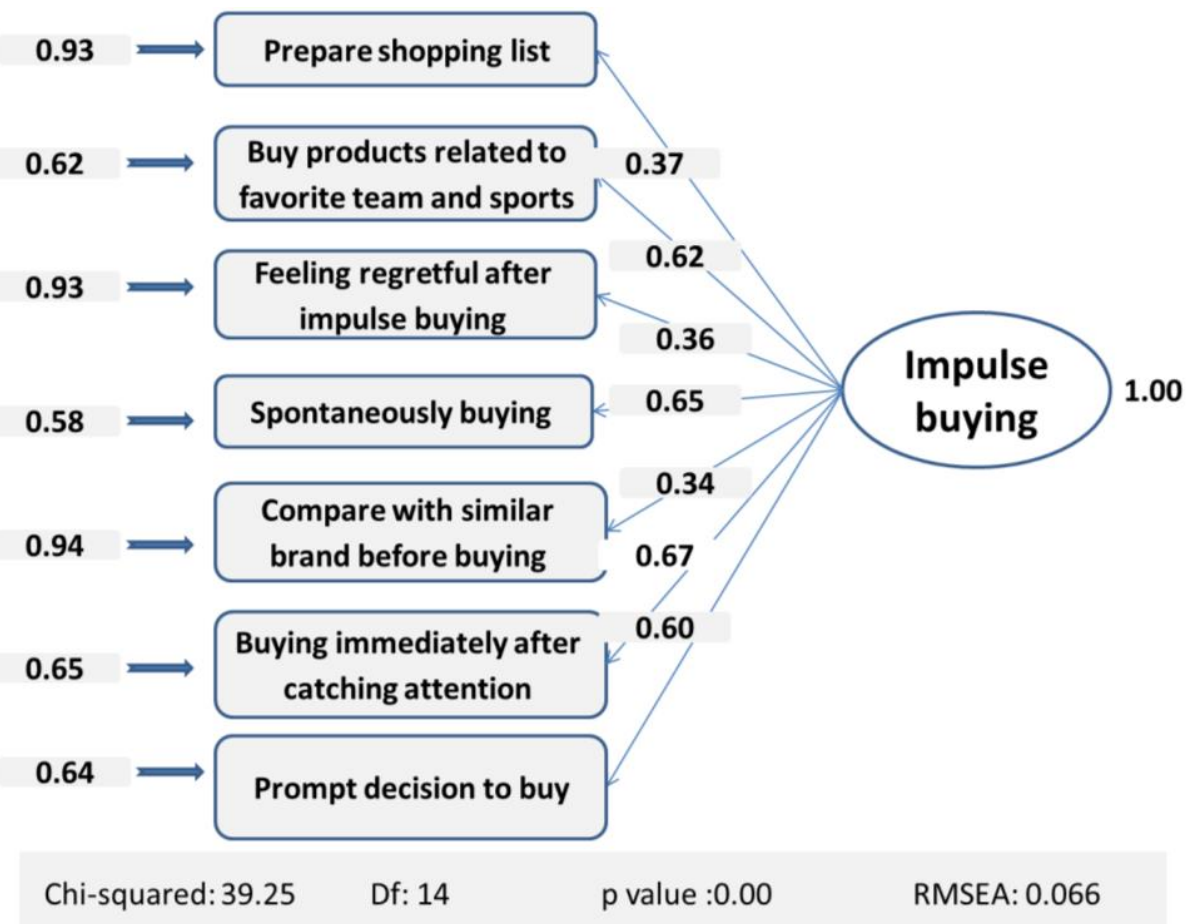

Figure 4. Confirmatory factor analysis chart of impulse buying scale 
Table 2 shows that the different fitting indicators calculated in this research and the values obtained for all the three factors affecting impulse buying in sports are all within the allowed range of these indicators.

Table 2. Fitting indicators of the relationship of factors affecting impulse buying behavior in sports customers

\begin{tabular}{|c|c|c|c|}
\hline Factors & Indicators & Allowed value & Results \\
\hline \multirow{7}{*}{ Situational } & $\chi^{2} / \mathrm{df}$ & $\chi^{2} / \mathrm{df}<3$ & 2.24 \\
\hline & $P$ - Value & $\mathrm{P}-$ Value $<0.05$ & 0.0001 \\
\hline & RMSEA & $<$ RMSEA $<0.080 .05$ & 0.05 \\
\hline & $\mathrm{t}$ & $<\mathrm{t}<1.96-1.96$ & 4.92 \\
\hline & AGFI & $0.85<$ & 0.9 \\
\hline & CFI & $0.9<$ & 0.94 \\
\hline & NFI & $0.9<$ & 0.92 \\
\hline \multirow{7}{*}{ Psychological-behavioral factors } & $\chi^{2} / \mathrm{df}$ & $\chi^{2} / \mathrm{df}<3$ & 2.38 \\
\hline & P - Value & $\mathrm{P}-$ Value $<0.05$ & 0.0001 \\
\hline & RMSEA & $<$ RMSEA $<0.080 .05$ & 0.036 \\
\hline & $t$ & $<\mathrm{t}<1.96-1.96$ & 5.58 \\
\hline & AGFI & $0.85<$ & 0.89 \\
\hline & CFI & $0.9<$ & 0.91 \\
\hline & NFI & $0.9<$ & 0.9 \\
\hline \multirow{7}{*}{ Product-related } & $\chi^{2} / \mathrm{df}$ & $\chi^{2} / \mathrm{df}<3$ & 2.56 \\
\hline & P - Value & $\mathrm{P}-$ Value $<0.05$ & 0.0001 \\
\hline & RMSEA & $0.05<$ RMSEA $<0.08$ & 0.037 \\
\hline & $\mathrm{t}$ & $-1.96<\mathrm{t}<1.96$ & 4.01 \\
\hline & AGFI & $0.85<$ & 0.9 \\
\hline & CFI & $0.9<$ & 0.92 \\
\hline & NFI & $0.9<$ & 0.91 \\
\hline
\end{tabular}

\section{DISCUSSION}

The present study aimed to develop an impulse buying scale in sports and validate it in 2017 at the level of sports stores in Tehran. The results of exploratory factor analysis show that all of the subscales had an acceptable value and, consequently, the internal consistency was appropriate. Situation factors with 6 items (beautiful showcase of stores, attractive environment of stores, guidance and skills of sellers, searching stores, individual buying, and enough money) with Cronbach's alpha mean of 0.7092 has the highest correlation. The research by Jamil (2016) with a Cronbach's alpha coefficient of 0.901 , by Wounkman \& Verhagen (2017) with a coefficient of 0.750 , Liao \& Chu (2016) with a coefficient of 0.885 , Lin (2015) with a coefficient of 0.808, Nazari \& Ghaderi (2011) with a coefficient of 0.832 , Nicbakht and Moshbeki (2014) with a coefficient of 0.859 , Rahimi et al. (2014) with a coefficient of 0.874 , Molki \& Dehghan (2013) with a coefficient of 0.746 , Sohrabi et al. (2014) with a coefficient of 0.849 , and Abedi et al. (2014) with a coefficient of 0.706 obtained results similar to the present study $(3,10-$ 12, 19-22). Also, the psychological-behavioral factors (including self-esteem, self-confidence, excitability, extraversion, buying pleasure, and quick decision making) with a mean Cronbach's alpha of 0.7039 had an acceptable value and, consequently, the internal correlation was appropriate. The research by Delfrooz \& Taleghani 
(2012) with Cronbach's alpha coefficient of 0.765 , Nikbakht \& Meshbehchi (2015) with coefficient of 0.892 , Rahimi et al. (2014) with coefficient of 0.751, Sohrabi et al. (2014) with a coefficient of 0.867, and Abedi et al. (2015) with a coefficient of 0.825 validated impulse buying through preparation of a scale. Also, Power et al. (2016) with a Cronbach's alpha coefficient of 0.901 , Leung (2017) with a coefficient of 0.798, Jamil (2016) with a coefficient of 0.901 , Liao \& Chu (2016) with a coefficient of 0.885 , Khan (2015) with a coefficient of $0.745, \mathrm{Lu}, \mathrm{Lin}, \&$ Hsu (2015) with a coefficient of 0.808 , Bsu (2015) with a coefficient of 0.901, Bellini, Gaurdinali, \& Grandi (2017) with a coefficient of 0.671 , and Drat (2017) with a coefficient of 0.838 validated impulse buying through preparation of an investigation scale $(10-12,22-27)$. Also, the product-related factors (including product type, sales strategy, discount, price, and brand) with a mean Cronbach's alpha of 0.7039 had an acceptable value and, consequently, internal correlation was appropriate. Rahimi et al. (2014) with a Cronbach's alpha coefficient of 0.751 , Maleki \& Dehghani (2014) with a coefficient of 0.725 , Sohrabi et al. (2014) with a coefficient of 0.867 , Prakash \& Shamra (2016) with a coefficient of 0.800 , Rezaei (2015) with a coefficient of 0.911, Khan (2016) with a coefficient of 0.75, Baghaian \& Vorma (2015) with a coefficient greater than 0.70 , Foroughi \& Sadeghi (2012) with a coefficient of 0.720, and Turkilmaz \& Ardam (2015) with an optimal number of 0.710 validated the subscales affecting impulse buying and obtained similar results $(9,11,28-31)$.

Factor loads derived from confirmatory factor analysis of items of situational, product-related impulse buying, and psychological-behavioral subscales in each case were greater than 0.3 (the least acceptable value): therefore, all the items related to this subscale can be categorized in separate factors.

The values obtained from fitness indicators show that all three factors affecting impulse buying in sports are within the allowed range of these indicators. Given the fact that the more the two AGFI and GFI indicators are closer to each other and the less the RMSEA index is, the most appropriate model fitting is shown: therefore, it can be seen that the data are in good agreement with the given model.
Hence, according to the results of exploratory analysis, confirmatory factor analysis and the values of fitness indicators, we can claim that the research hypothesis is confirmed. In other words, the data developed scale of the research can be considered an appropriate scale with validity and reliability to determine the factors affecting impulse buying behavior in sports.

\section{CONCLUSION}

Based on the results of the present study, it can be concluded that all the items related to situational, psychological-behavioral factors, and product-related factors effective on impulse buying have appropriate validity and reliability. Due to lack of a rich and suitable research background for impulse buying in the field of sports and sport consumers, as well as the limitation of the present study to examine all the items related to the factors affecting impulse buying, we can conclude that the subscales studied had credibility. Hence, it is suggested that researchers can use the current scale in calculating factors stimulating customers to impulse buying. According to the attitudes and behaviors of customers and sports consumers, and given the results of this research, researchers may deal with the preparation of strategies for sales management. Also, due to research limitations, it is suggested to use other appropriate items to explain impulsive behavior of sports consumers, especially in online shopping spaces.

\section{APPLICABLE REMARKS}

- Sports marketers and marketing researchers can use this scale to measure the factors affecting the behavior of impulse buying in sports.

- Using this scale and the results they gain, sports managers and decision makers can prepare a marketing and sales strategy.

- Due to the increasing development of ecommerce, this scale can be used with minor revisions for investigating the factors affecting impulse buying in sports. 


\section{REFERENCES}

1. Vonkeman C, Verhagen T, van Dolen W. Role of local presence in online impulse buying. Information \& Management. 2017;54(8):1038-48. [DOI:10.1016/j.im.2017.02.008]

2. Chen C-C, Yao J-Y. What drives impulse buying behaviors in a mobile auction? The perspective of the StimulusOrganism-Response model. Telematics and Informatics. 2018. [DOI:10.1016/j.tele.2018.02.007]

3. Abbasi B. Relationship between Consumer Characteristics and Impulse Buying Behavior: The Mediating Role of Buying Intention of New Clothing Buyers. International Review of Management and Marketing. 2017;7(1).

4. Nizam N, Lee S. The impact of impulse buying behavior on customers purchasing decisions. Journal of Fundamental and Applied Sciences. 2018;10(6S):2566-71.

5. Chen C-Y, Lin Y-H, Chang W-M. Impulsive Purchasing Behavior for Professional Sports Team-Licensed Merchandise-From the Perspective of Group Effects. Sport Marketing Quarterly. 2013;22(2):83.

6. Salman M, Khan S, Gul MSA. Factors influencing impulse buying of sports team merchandise in developing country: an empirical investigation. Pakistan Journal of Commerce and Social Sciences. 2014;8(1):185.

7. Kwon HH, Armstrong KL. Impulse purchases of sport team licensed merchandise: what matters? Journal of Sport Management. 2006;20(1):101-19. [DOI:10.1123/jsm.20.1.101]

8. Atulkar S, Kesari B. Role of consumer traits and situational factors on impulse buying: does gender matter? International Journal of Retail \& Distribution Management. 2018;46(4):386-405. [DOI:10.1108/IJRDM-12-20160239]

9. nazari m, Baghdadi m. Investigating the Factors that Influence Online Impulsive Buying in Iran - Survey on Group Discount Websites. Journal of Information Technology Management. 2013;5(3):223-39. [Article in farsi].

10. Nazari M, Ghaderi Abed AH. Developing a Model to Evaluating Effective Factors on Impulse Buying Behavior. Iranian Business Management. 2011;3(10):127-40. [Article in farsi].

11. Esfahani ME, Hadadian A, Rahimizadeh H. Evaluating Effective Factors on Impulse Buying at Chain Store in Mashhad:(Case Study: Poruma Chain Store). New Marketing Research Journal. 2014;4(4):71-84. [Article in farsi].

12. Abedi B, Asgari N, Safari H, Assadzadeh A, Rahnama A. The facilitating effect of individual, environmental and fashion involvement factors on impulse buying. Iranian Business Management. 2015;7(1):127-44.

13. Gangai KN, Agrawal R. The Influence of Personality Traits on Consumer Impulsive Buying Behaviour. International Journal of Marketing \& Business Communication. 2016;5(1). [DOI:10.21863/ijmbc/2016.5.1.027]

14. Zhu H, Yang Z, Ou CX, Liu H, Davison RM. Investigating the Impacts of Recommendation Agents on Impulsive Purchase Behaviour. arXiv preprint arXiv:160601349. 2016.

15. Sumetha MM, Vasanthi S. Factors Influencing Online Impulsive Buying Behaviour.

16. Pawar PA, Shastri D, Raut UR. In-store sampling and impulsive buying behavior: An empirical approach. IJAR. 2016;2(4):304-7.

17. Akram U, Hui P, Khan MK, Hashim M, Rasheed S. Impact of store atmosphere on impulse buying behaviour: Moderating effect of demographic variables. International Journal of u-and e-Service, Science and Technology. 2016;9(7):43-60. [DOI:10.14257/ijunesst.2016.9.7.05]

18. Bhuvaneswari MV, Krishnan J. A Review of Literature on Impulse Buying Behaviour of Consumers in Brick \& Mortar and Click only Stores.

19. Lo LY-S, Lin S-W, Hsu L-Y. Motivation for online impulse buying: A two-factor theory perspective. International Journal of Information Management. 2016;36(5):759-72. [DOI:10.1016/j.ijinfomgt.2016.04.012]

20. Liao SL, Shen YC, Chu CH. The effects of sales promotion strategy, product appeal and consumer traits on reminder impulse buying behaviour. International Journal of Consumer Studies. 2009;33(3):274-84. [DOI:10.1111/j.1470-6431.2009.00770.x]

21. Jamil F. The Role of Installment Buying Plans in Increasing the Impulse Buying Behavior among Jordanian House Holds. Journal of Management Research. 2015;8(1):110-24. [DOI:10.5296/jmr.v8i1.8625]

22. sohrabi r, Samadi A, Yoosofifard a. Recognize Effective Factors On Impulse Buying Behavior (Unplanned) Of Customers (Case Study: Refah Chain Stores In Hamadan). Scientific Journal Management System. 2014;6(11):147-82. [Article in farsi].

23. Bellini S, Cardinali MG, Grandi B. A structural equation model of impulse buying behaviour in grocery retailing. Journal of Retailing and Consumer Services. 2017;36:164-71. [DOI:10.1016/j.jretconser.2017.02.001]

24. Darrat AA, Darrat MA, Amyx D. How impulse buying influences compulsive buying: The central role of consumer anxiety and escapism. Journal of Retailing and Consumer Services. 2016;31:103-8. [DOI:10.1016/j.jretconser.2016.03.009]

25. Khan N, Hui LH, Chen TB, Hoe HY. Impulse buying behaviour of Generation Y in fashion retail. International Journal of Business and Management. 2015;11(1):144. [DOI:10.5539/ijbm.v11n1p144] 
26. Khuong MN, Tran TB. Factors Affecting Impulse Buying toward Fashion Products in Ho Chi Minh City--A Mediation Analysis of Hedonic Purchase. International Journal of Trade, Economics and Finance. 2015;6(4):223. [DOI:10.7763/IJTEF.2015.V6.473]

27. Leong L-Y, Jaafar NI, Sulaiman A. Understanding impulse purchase in Facebook commerce: does Big Five matter? Internet Research. 2017;27(4):786-818. [DOI:10.1108/IntR-04-2016-0107]

28. Badgaiyan AJ, Verma A. Does urge to buy impulsively differ from impulsive buying behaviour? Assessing the impact of situational factors. Journal of Retailing and Consumer Services. 2015;22:145-57. [DOI:10.1016/j.jretconser.2014.10.002]

29. Prakash A, Sharma A. Dimensions of point of purchase factors in impulsive buying of women's skincare cosmetics in India. Journal of Business and Retail Management Research. 2016;10(2).

30. Rezaei S, Ali F, Amin M, Jayashree S. Online impulse buying of tourism products: the role of web site personality, utilitarian and hedonic web browsing. Journal of Hospitality and Tourism Technology. 2016;7(1):60-83. [DOI:10.1108/JHTT-03-2015-0018]

31. Turkyilmaz CA, Erdem S, Uslu A. The effects of personality traits and website quality on online impulse buying. Procedia-Social and Behavioral Sciences. 2015;175:98-105. [DOI:10.1016/j.sbspro.2015.01.1179] 